\title{
Effects of Droplet-Vitrification Cryopreservation Based on Physiological and Antioxidant Enzyme Activities of Brassidium Shooting Star Orchid
}

\author{
Safrina Rahmah, Safiah Ahmad Mubbarakh, \\ Khor Soo Ping, and Sreeramanan Subramaniam \\ School of Biological Sciences, Universiti Sains Malaysia (USM), 11800 Penang, Malaysia \\ Correspondence should be addressed to Sreeramanan Subramaniam; sreeramanan@usm.my
}

Received 31 December 2014; Accepted 6 February 2015

Academic Editor: Mehmet Yakup Arica

Copyright (C) 2015 Safrina Rahmah et al. This is an open access article distributed under the Creative Commons Attribution License, which permits unrestricted use, distribution, and reproduction in any medium, provided the original work is properly cited.

Protocorm-like bodies (PLBs) of Brassidium Shooting Star orchid were successfully cryopreserved using droplet-vitrification method. Vitrification based cryopreservation protocol is comprised of preculture, osmoprotection, cryoprotection, cooling, rewarming, and growth recovery and each and every step contributes to the achievement of successful cryopreservation. In order to reveal the lethal and nonlethal damage produced by cryopreservation, histological observation, scanning electron microscopy (SEM), and biochemical analysis were carried out in both cryopreserved and noncryopreserved PLBs of Brassidium Shooting Star orchid comparing with the control PLBs stock culture. Histological and scanning electron microscopy analyses displayed structural changes in cryopreserved PLBs due to the impact of cryoinjury during exposure to liquid nitrogen. Total soluble protein significantly increased throughout the dehydration process and the highest value was achieved when PLBs were stored in liquid nitrogen. Ascorbate peroxidase (APX) and catalase (CAT) showed the highest enzyme activities in both dehydration and cryostorage treatments indicating that stress level of PLBs was high during these stages.

\section{Introduction}

Conservation of orchid germplasm is important to protect biodiversity and also to store elite plants, the latter being necessary for the improvement and maintenance of new cultivars [1]. Orchidaceae belonging to 800 genera consists of almost 35,000 species and more than 150,000 artificial hybrids [2,3]. A new orchid genus named Brassidium has been produced from the crosses of two genera Brassia and Oncidium. The unique colour combination of species and hybrids in these groups makes them as one of the popular traded groups with highly consumer demand [4]. Cryopreservation has become an important and valuable tool for long-term storage of germplasm via ex situ conservation. Cryopreservation refers to the process of freezing living materials at ultralow temperature of liquid nitrogen which allows the safe and cost effective long-term conservation for many plant cells and tissues $[5,6]$. At this low temperature, all metabolic processes and cellular divisions were halted. Therefore, plant germplasm materials can be stored stably for unlimited durations [7].

Several factors which are involved in cryopreservation procedures promote stresses and cryoinjury to the plant. This includes changes in cellular structure, deterioration of the plasma membrane, and alteration of enzyme activity [8]. Water content is the critical factor in succesfull cryopreservation. Reducing water content from cells is important to avoid the phenomenon of ice crystallization. Cell damages commonly take place in osmoprotection and dehydration process as the cells do not withstand the osmotic stress when water is removed from protoplasm [9]. Besides that, cryoinjury induced by intracellular ice formation also promotes cell death during cooling and warming process. This is due to the uneven distribution of cryoprotectant throughout the cells, thus resulting in intracellular ice formation in several parts of the cells [10]. To study the effects of cryopreservation 
procedure to the plant, various analyses such as histological scanning electron microscopic observation and biochemical analysis can be done. Several numbers of histological studies using light microscopy have been reported to characterise and have better understanding of dehydration and freezing effect on cryopreserved cells [11, 12]. Scanning electron microscopy has also been carried out to observe the biological surface structure of the explants following cryopreservation [13-15].

In vitrification-based cryopreservation, plant materials were exposed to stress due to excision, dehydration, and changes in temperature during freezing and warming. Uncontrolled production of reactive oxygen species (ROS) was known as the main factor of causing reduction in cryopreserved explants regeneration and cell death after rewarming [16]. ROS are products of various normal cellular metabolism pathways in plants [17]. It comprises superoxide radicals, singlet oxygen, hydrogen peroxide, and hydroxyl radicals. They are highly reactive and toxic which can cause significant damage to cell components [18, 19]. Many abiotic stresses such as heavy metals, light intensity, drought, wounding, and extreme changes in temperature induce the overproduction of ROS. When production of ROS is higher than antioxidant in the cells, it results in oxidative stress and leads to cell death. To protect the cells against toxic effect of ROS, plants have developed natural antioxidant defence mechanisms [20]. ROS production is controlled by enzymatic antioxidant system such as superoxide dismutase (SOD), catalase (CAT), ascorbate peroxidase (APX), glutathione reductase (GR) and nonenzymatic antioxidative including ascorbic acid (ASH), glutathione (GSH), and $\alpha$-tocopherols. If antioxidant defences are compromised, uncontrolled production of ROS will lead to oxidative damage to lipids, proteins, and DNA. Enzymatic antioxidants protect the cells by transforming ROS into stable inactive products and avoiding production of lipid peroxidation. On the other hand, nonenzymatic antioxidants act by scavenging ROS, stopping toxic byproducts of metal ions, and inhibiting the complex radical chain reactions [21]. Antioxidant supplements can increase the regeneration of some plant and algal cells from cryostorage [22, 23]. It has been used as freezing tolerance marker in the number of cryopreservation experiments [24-26].

Catalase $\left(\mathrm{H}_{2} \mathrm{O}_{2}\right.$ oxidoreductase $)$ which is a heme-containing enzyme catalyses the dismutation of $\mathrm{H}_{2} \mathrm{O}_{2}$ into $\mathrm{H}_{2} \mathrm{O}$ and $\mathrm{O}_{2}$ generated in peroxisomes during oxidative stress $[27,28]$. Proliferation of peroxisomes during stresses aids in scavenging $\mathrm{H}_{2} \mathrm{O}_{2}$ diffusing from cytosol [29]. One molecule of catalase converts 6 million molecules of $\mathrm{H}_{2} \mathrm{O}_{2}$ to $\mathrm{H}_{2} \mathrm{O}$ and $\mathrm{O}_{2}$ and is said to have one of the highest turnover rates for all enzymes [19]. Besides reaction with $\mathrm{H}_{2} \mathrm{O}_{2}$, catalase also encounters hydroperoxidases such as methyl hydrogen peroxide $(\mathrm{MeOOH})$ [30]. Catalase reduces $\mathrm{H}_{2} \mathrm{O}_{2}$ intensity in peroxisomes whereas APX carry out this role in chloroplast and cytosol of plant cells [31]. APX uses ascorbate as a hydrogen donor to break down $\mathrm{H}_{2} \mathrm{O}_{2}$ to form $\mathrm{H}_{2} \mathrm{O}$ and monodehydroascorbate (MDHA) [32]. APX has a higher affinity for $\mathrm{H}_{2} \mathrm{O}_{2}$ ( $\mu \mathrm{M}$ range) than CAT and POD ( $\mu \mathrm{M}$ range) and it may have a more essential role during stress [19].
The overproduction of APX amplified the POD activity which fortifies the ROS scavenging system and helps in oxidative stress tolerance [33]. Therefore, the objective of this study is to identify the effects of droplet vitrification cryopreservation procedure on PLBs of Brassidium Shooting Star orchid through histological analysis, SEM, and several biochemical assays (total soluble protein, APX, and CAT).

\section{Materials and Methods}

2.1. Planting Materials. In vitro culture of Brassidium Shooting Star orchid PLBs were initiated by aseptically culturing basal corms of orchid hybrid on half-strength MS media supplemented with $1 \mathrm{mg} / \mathrm{L}$ 6-benzylaminopurine (BAP), $2 \%$ sucrose, and $2.75 \mathrm{~g} / \mathrm{L}$ Gelrite. Cultures were grown at $25 \pm$ $2^{\circ} \mathrm{C}$ under 16 -hour photoperiod and subcultured every three weeks.

2.2. Droplet Vitrification. For cryopreservation procedure, PLBs 3-4 mm in size were cultured in half-strength semisolid MS media supplemented with $0.25 \mathrm{M}$ at $25 \pm 2^{\circ} \mathrm{C}$ for 7 days under 16-hour photoperiod. PLBs were then treated with $4 \mathrm{~mL}$ of loading solution (osmoprotection) for 20 minutes at room temperature followed by dehydration with $4 \mathrm{~mL}$ of ice cooled PVS2 solution (cryoprotection) for 40 minutes. PLBs were then dropped with $15 \mu \mathrm{L}$ PVS2 solution on aluminium strips $(5 \times 20 \mathrm{~mm})$ and plunged into liquid nitrogen. For rewarming, aluminium strips were taken out from the vial and quickly plunged into $4 \mathrm{~mL}$ unloading solution containing $1.2 \mathrm{M}$ sucrose for 15 minutes at room temperature. PLBs were then transferred into half-strength MS media supplemented with $20 \mathrm{~g} / \mathrm{L}$ sucrose and $2.75 \mathrm{~g} / \mathrm{L}$ Gelrite, kept for two weeks in the dark condition, and then exposed to 16-hour photoperiod. Cryopreserved PLBs were transferred into half-strength semisolid MS media enriched with $1 \mathrm{mg} / \mathrm{L}$ BAP, $20 \mathrm{~g} / \mathrm{L}$ sucrose, and $2.75 \mathrm{~g} / \mathrm{L}$ Gelrite 4 weeks after cryotreatment.

2.3. Histological Analysis. In sample preparation for histological study, PLBs were fixed with formaldehyde (FAA) (95\% ethyl alcohol: glacial acetic acid : formaldehyde: water, $10: 1: 2: 7)$ for $48 \mathrm{~h}$. After $24 \mathrm{~h}$ washing under running tap water, PLBs were then dehydrated with graded series of tertiary-butyl alcohol (TBA). After dehydration, PLBs were exposed to xylene for 10 minutes followed by combination of xylene and Shandon Histoplast Pelletised Paraffin Wax for 30 minutes at $60^{\circ} \mathrm{C}$ oven. Subsequently the samples were then treated with wax I, II, and III (increasing concentration of Shandon Histoplast Pelletised Paraffin Wax) for 1 hour, respectively, at $60^{\circ} \mathrm{C}$ oven. Specimen was then blocked by pouring melted Shandon Histoplast Pelletised Paraffin Wax into mould to form wax blocks and the samples were immediately positioned inside the wax block. The block was sliced with 10 Micron Microtome and the sliced ribbons were then attached to clean glass slide and kept in $40^{\circ} \mathrm{C}$ oven for 24 hours. Specimen was then stained with safranin and fast green. The observation of slides was conducted using light microscope. 


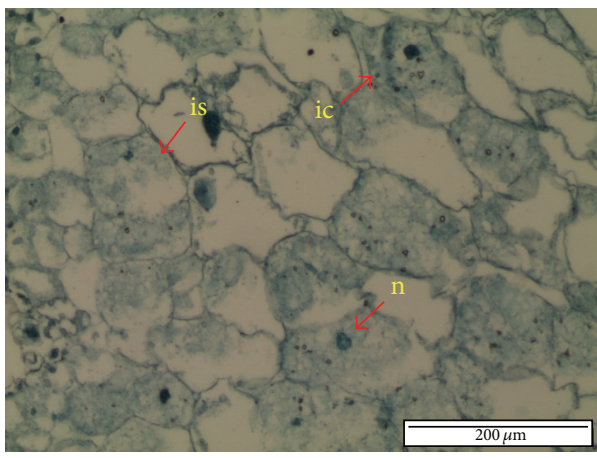

(a)

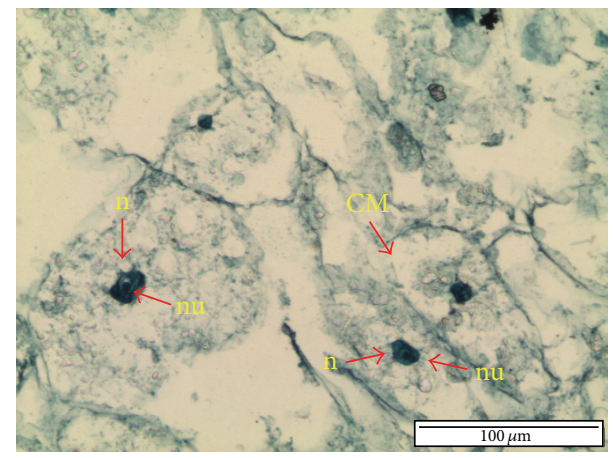

(b)

FIgure 1: Cross-section of stock culture PLB. (a) The cells were intact with isodimetric shape and nucleus in central position. (b) Nucleus contains nucleolus and mitotic activities were observed (CM: cell mitosis; ic: intact cell; is: isodiametric; n: nucleus; nu: nucleolus).

2.4. Scanning Electron Microscope Analysis. PLBs were exposed to $2 \%$ osmium tetraoxide for vapour fixation process for 2 hours. Once the samples have been fixed, the planchette is plugged into slushy nitrogen $\left(-210^{\circ} \mathrm{C}\right)$ and then transferred to the peltier-cooled stage of freeze dryer and left to freeze dry for 10 hours. The samples were spotted with about 5 to $10 \mathrm{~nm}$ of gold before viewing in scanning electron microscope.

2.5. Biochemical Analysis. In this study total soluble protein content, ascorbate peroxidise (APX) and catalase (CAT) enzymes activities were monitored separately after treatment of each cryopreservation step such as preculture, loading, PVS2, storage in LN, unloading, and recovery after 4 days of treatment. Fresh PLBs extracts were prepared at $4^{\circ} \mathrm{C}$ and activity assays were determined spectrophotometrically [3437].

For total soluble protein content, about $1 \mathrm{~g}$ of PLBs was ground and homogenized in $3 \mathrm{~mL}$ of protein extraction buffer that contained $0.1 \mathrm{M}$ Tris hydrochloric acid, $1.0 \mathrm{mM}$ EDTA, and $0.1 \%$ mercaptoethanol $(\mathrm{pH} 8)$. The crude extracts were aliquoted into $1.5 \mathrm{~mL}$ microcentrifuge tubes and centrifuged at $12,000 \mathrm{rpm}$ for 20 minutes $\left(4^{\circ} \mathrm{C}\right)$. Total $20 \mu \mathrm{L}$ of PLB extract and $80 \mu \mathrm{L}$ of protein extraction buffer were added into test tube containing $5 \mathrm{~mL}$ of protein reagent $(100 \mathrm{mg}$ Coomassie Brilliant Blue G-250, $50 \mathrm{~mL}$ of $95 \%$ ethanol, and $100 \mathrm{~mL}$ of $85 \%(\mathrm{w} / \mathrm{v})$ phosphoric acid were dissolved and topped up to $1 \mathrm{~L}$ with double distilled water $(\mathrm{pH} 7.0))$. The mixture was then incubated for 2 minutes and total protein content was measured using spectrophotometer at $595 \mathrm{~nm}$. The protein content was compared with standard bovine serum albumin (BSA).

The protocol for enzyme extraction in APX assay was performed based on Elavarthi and Martin [38] method. About $200 \mathrm{mg}$ of PLB was ground and homogenized in $1.2 \mathrm{~mL}$ of $0.2 \mathrm{M}$ potassium phosphate buffer $(\mathrm{pH} 7.8$ with $0.1 \mathrm{mM}$ EDTA). The extracts were transferred into $1.5 \mathrm{~mL}$ microcentrifuge tubes and centrifuged at 13,000 rpm for 20 minutes. The supernatant was removed and the pellets were resuspended with $0.8 \mathrm{~mL}$ of the same buffer and centrifuged at $13,000 \mathrm{rpm}$ for 15 minutes. APX activity was monitored using Nakano and Asada [35] method. The $3 \mathrm{~mL}$ assay contained $50 \mathrm{mM}$ potassium phosphate buffer ( $\mathrm{pH} 7.0$ ), $0.5 \mathrm{mM}$ ascorbate, $0.5 \mathrm{mM} \mathrm{H}_{2} \mathrm{O}_{2}$, and $30 \mu \mathrm{L}$ of PLB's supernatant obtained from each step of cryopreservation protocol. The reaction was initiated by adding $\mathrm{H}_{2} \mathrm{O}_{2}$ at last. The decrease of absorbance was monitored for every 30 seconds up to 3 minutes using a spectrophotometer set at $290 \mathrm{~nm}$. The reduction of ascorbate was calculated using an extinction coefficient of $2.8 \mathrm{M}^{-1} \cdot \mathrm{cm}^{-1}$.

The protocol for enzyme extraction in CAT assay was performed based on Samantary [39] and Monnet et al. [37]. About $100 \mathrm{mg}$ of PLB crude was homogenized in $10 \mathrm{~mL}$ of $100 \mathrm{mM}$ potassium phosphate buffer ( $\mathrm{pH} 7.8$ with $2 \mathrm{mM}$ EDTA ferric sodium and $2 \%$ polyvinylpyrrolidone), transferred into $50 \mathrm{~mL}$ centrifuge tubes, and centrifuged at $9000 \mathrm{rpm}$ for 30 minutes. The quantification of CAT activity was determined using modified protocol used by Cakmak and Marschner [36] and Monnet et al. [37]. The $3.1 \mathrm{~mL}$ aliquot contained $100 \mathrm{mM}$ potassium phosphate buffer $(\mathrm{pH} 7.0)$ and $100 \mu \mathrm{L}$ of PLB extract obtained from each step of cryopreservation protocol. The reaction was initiated by adding $6 \mathrm{mM} \mathrm{H}_{2} \mathrm{O}_{2}$. The decrease of absorbance was monitored for every 30 seconds up to 3 minutes using a spectrophotometer set at $240 \mathrm{~nm}$. The decomposition of hydrogen peroxide was calculated using an extinction coefficient of $40 \mathrm{mM}^{-1} \cdot \mathrm{cm}^{-1}$.

The APX and CAT enzyme activities were expressed in unit of catalase $\left(\mathrm{U} \cdot \mathrm{mL}^{-1}\right)$. Enzyme activities were calculated using Tijssen [40] and Flocco and Giuliettti [41] formula.

\section{Results}

3.1. Histology and Scanning Electron Microscopy of PLBs. Structural analysis of PLBs was observed using light and scanning electron microscopy. Cellular changes of stock culture and cryopreserved and noncryopreserved PLBs were monitored eight weeks after treatment. For histological analysis, cross-section of stock culture PLB showed that the shape of cells remained intact (Figure 1). There was no damage or cell plasmolysis observed, as cytoplasm was well preserved 


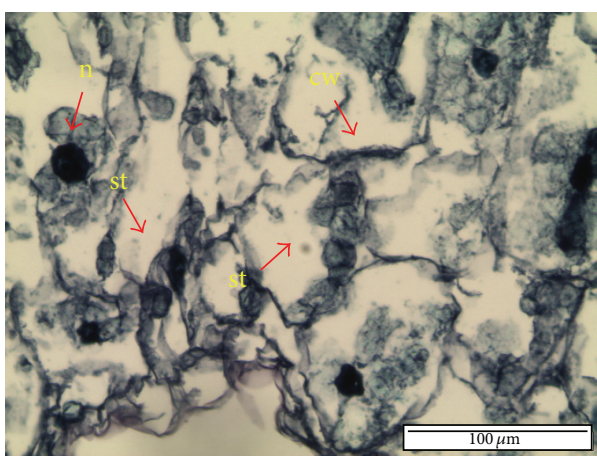

(a)

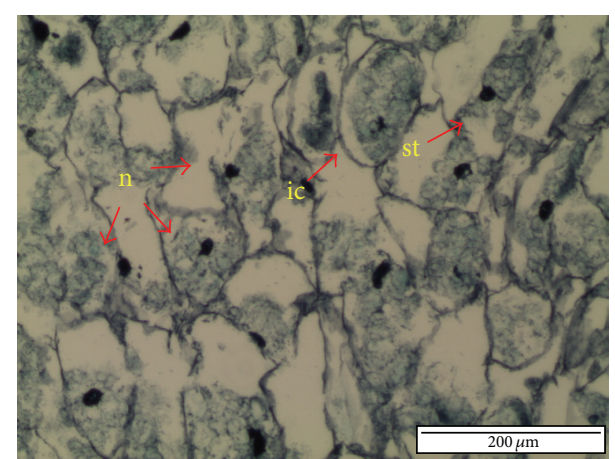

(b)

FIGURE 2: Cross-section of noncryopreserved PLB. (a) Original PLB. Nucleus was deeply stained, cell walls were thickening, and starch grains were dense. (b) Regenerated portion. Cells were intact with dense nuclei, and some starch was observed (ic: intact cell; cw: cell wall; n: nucleus; st: starch).

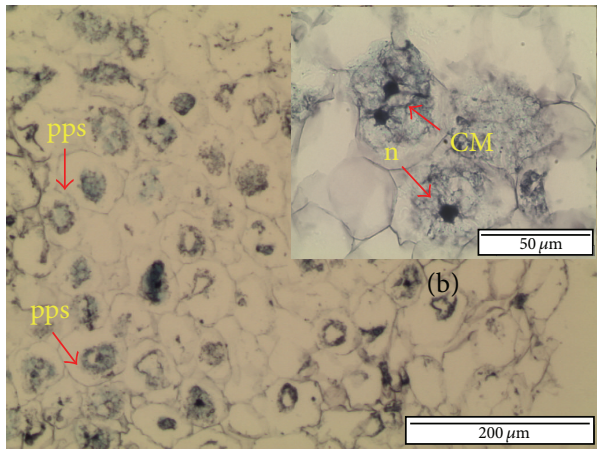

(a)

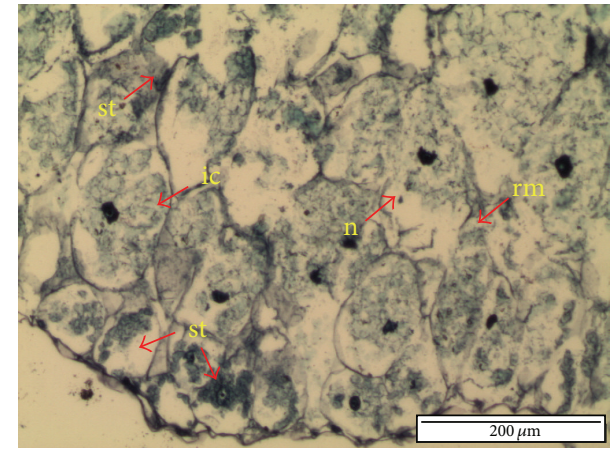

(c)

FIGURE 3: Cross-section of cryopreserved PLB. (a) Original PLB. Cells were in plasmolysis and pps were significant. (b) Higher magnification showing cell being intact and mitotic activity in cryopreserved PLB. (c) Regenerated portion. Cells were intact with dense nuclei, and some rupture membrane and starch were observed (CM: cell mitosis ic: intact cell; n: nucleus; pps: periplasmic space; rm: rupture membrane; st: starch).

and displayed a very small periplasmic space. The densely stained cytoplasm contained a centrally positioned nucleus and clearly visible nucleoli. The mitosis activity was also noticed in the stock culture PLB.

In this study, $73 \%$ regrowth was obtained when PLBs were treated with optimised cryopreservation protocols. PLBs that were precultured on $0.25 \mathrm{M}$ sucrose for 7 days were treated with 20 minutes loading solution, followed by 40 minutes dehydration with PVS2 before plunging into liquid nitrogen. In noncryopreserved treatment, PLBs were directly rinsed with 1.2 M sucrose for 15 minutes after PVS2 dehydration treatment. Histological analysis revealed that dehydration process does not affect cellular structural of noncryopreserved PLBs (Figure 2). Cross-section of original and regenerated noncryopreserved PLB displayed intact cells, voluminous nucleus, and dense cytoplasm. Starch accumulation was clearly observed in both original and regenerated PLBs.

Figure 3 displayed the effect of liquid nitrogen in cellular changes of PLB. Cross-section of cryopreserved PLB was less stained compared to the control. The cells experienced plasmolysis as cytoplasm shrunk and significant periplasmic spaces were noticed (Figure 3(a)). Nonetheless, mitotic activity was observed in the cryopreserved PLB (Figure 3(b)). This indicates that cryopreserved PLB successfully conserved living cells that would regenerate into new plantlets. However, cross-section of regenerated portion of cryopreserved PLB displayed structure similar to that of stock culture (Figure 3(c)). The PLBs were recovered with no damages and reduced periplasmic space. The nuclei were dense and highly stained. Starch accumulation was also visible in this PLB.

SEM studies of both cryopreserved and noncryopreserved PLBs presented varying effects of the treatment using cryoprotectant and liquid nitrogen. Surface of both cryopreserved and noncryopreserved PLBs showed damage compared to stock culture (Figure 4). Stock culture PLB remain intact with randomly distributed stomata on the surface (Figure 4(a)). Contrarily, SEM analysis of cryopreserved PLB exhibited cracked on the surface (Figure 4(c)). However, highly magnified image of cryopreserved PLB (Figure $4(\mathrm{~d})$ ) showed the presence of intact cells indicating recovery of tissues and chances of regeneration. On the other hand, 


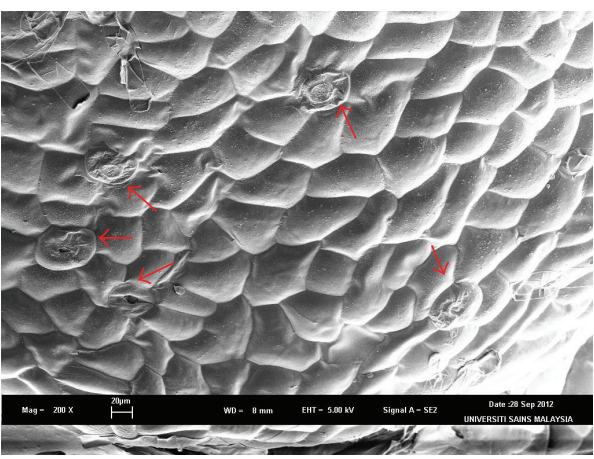

(a)

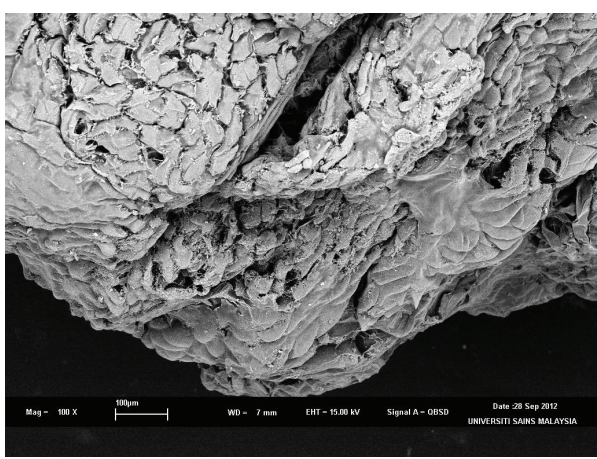

(c)

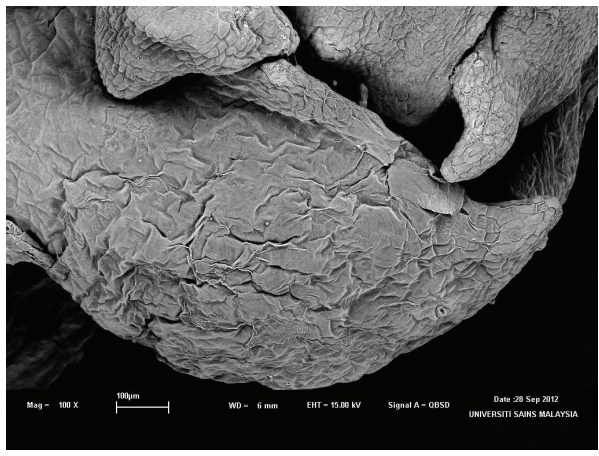

(e)

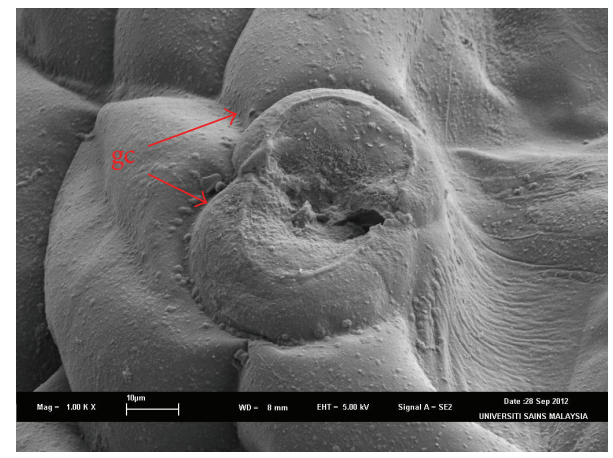

(b)

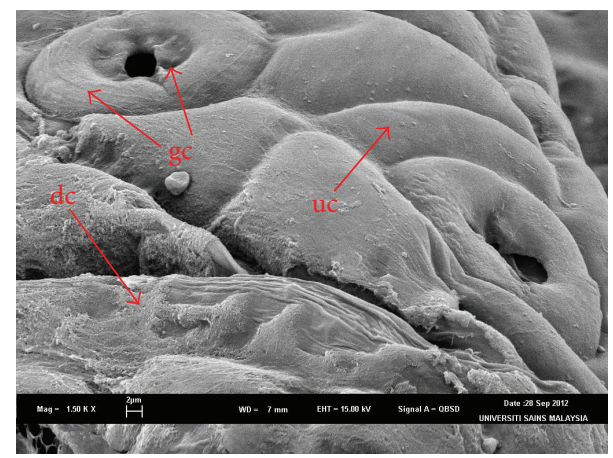

(d)

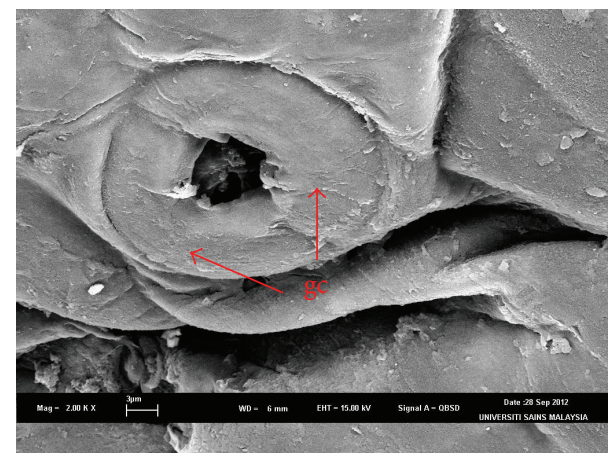

(f)

FIGURE 4: Scanning electron microscopic of stock culture, cryopreserved and noncryopreserved PLBs. (a) stock culture PLB with dense stomata on its surface (arrows), (b) higher magnification of stomata in stock culture PLB, (c) cryopreserved PLB showing damage, (d) higher magnification of cryopreserved PLB showing stomata and damage and undamaged cells, (e) noncryopreserved PLB shrunk, and (f) higher magnification showing stomata of noncryopreserved PLB (dg: damage cell; gc; guard cell; ud: undamaged cell).

noncryopreserved PLB did not exhibit detrimental effects observed on the cryopreserved PLB. However, the noncryopreserved PLB shrunk indicating a minimal damage to the surface (Figure 4(e)). Cryopreserved and noncryopreserved PLBs were shown to be similar to the stock culture in terms of the occurrence of stomata. Both tissues exhibited randomly distributed oval-shaped stomata formed by intact guard cells (Figures 4(d) and 4(f)).

3.2. Biochemical Analyses. Cryopreservation procedures significantly affected the total soluble protein and enzyme activity of treated PLB (Figures 5-7). Increases in total soluble protein of PLBs were observed during early stage of cryopreservation, that is, preculture and loading treatment, when compared to control PLBs. There were slight decreases of total soluble protein content during PVS2 dehydration; however, the highest value was significantly achieved when PLBs were stored in liquid nitrogen (Figure 5). The total soluble protein content further decreased during unloading and recovery treatment and there were no significant differences compared to control. Catalase and ascorbate peroxidase displayed the highest antioxidant activity in both dehydration and cryostorage treatments (Figures 6 and 7). During preculture and loading treatment, APX activity is relatively low and did not 


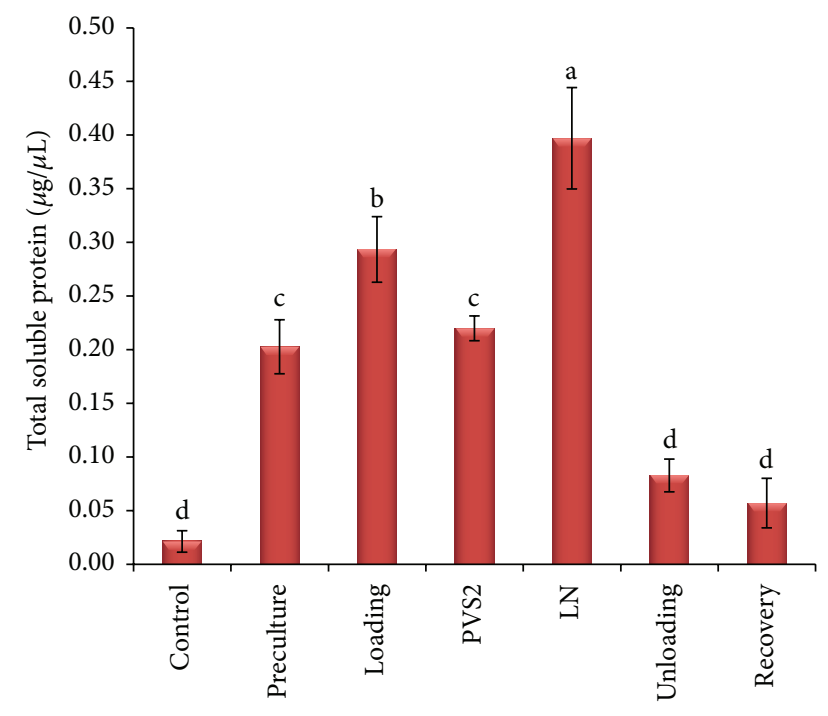

FIgURE 5: Total soluble protein contents of PLBs sampled at various stages of the cryopreservation. Results were analysed using oneway ANOVA. Means followed by the same alphabet were not significantly different using Tukey test.

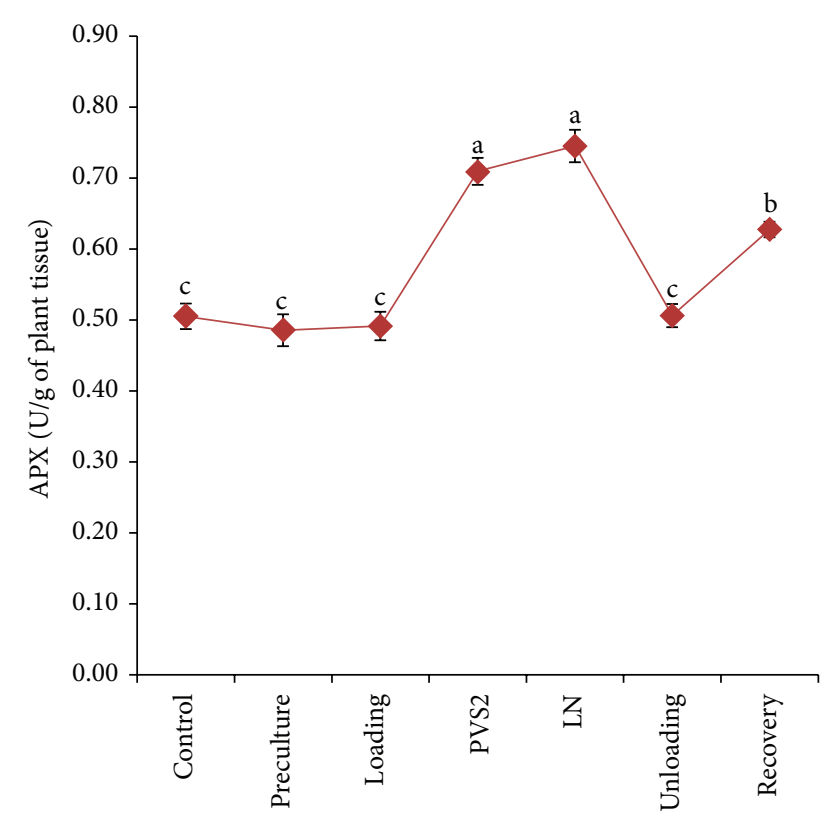

FIGURE 6: Changes in ascorbate peroxidase (APX) enzyme activity at various stages of the cryopreservation. Results were analysed using one-way ANOVA. Means followed by the same alphabet were not significantly different using Tukey test.

show significant different with control (Figure 6). On the other hand, CAT activity represents a gradual increase from control to PVS2 dehydration treatment and subsequently decreases after liquid nitrogen storage until growth recovery stage (Figure 7).

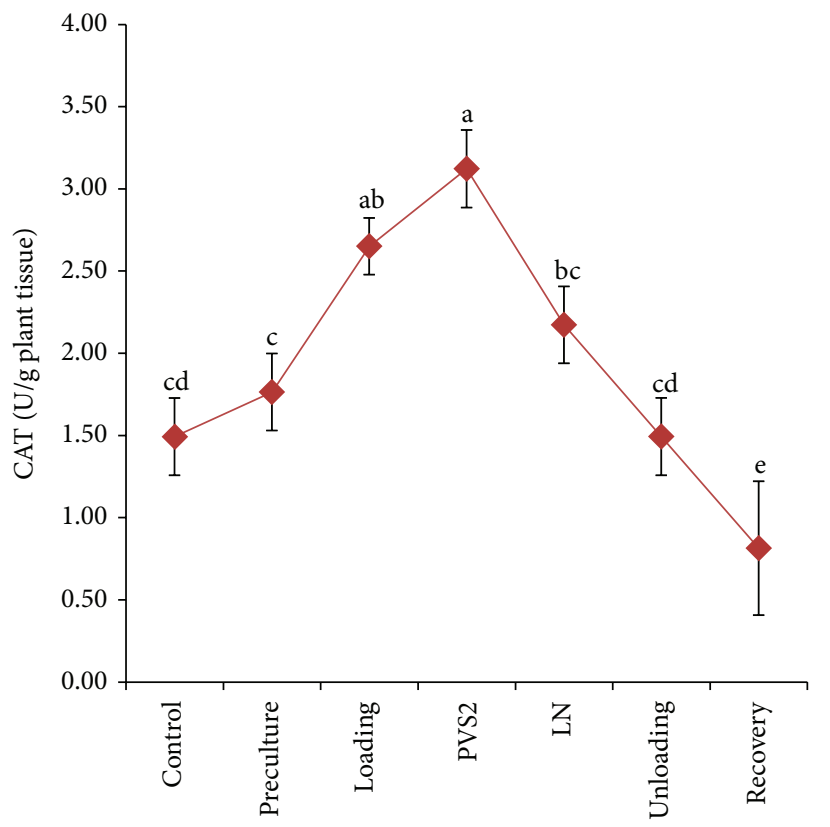

FIgURE 7: Changes in catalase (CAT) enzyme activity at various stages of the cryopreservation. Results were analysed using oneway ANOVA. Means followed by the same alphabet were not significantly different using Tukey test.

\section{Discussion}

Excessive amount of water in cells may crystallize while lower amount of water causes cells to shrink during the event of cryopreservation of tissues. Hence, maintaining a balance water content in cells is the utmost factor to achieve sucessful cryopreservation of a tissue. Additional PVS2 solution was commonly used in vitrifcation-based cryopreservation for cell dehydration and changing behaviour of remaining water within the cells [42]. During cryopreservation procedures the damage will firstly occur in the cell membrane and results in cell death $[10,43]$. Cryopreserved plant which successfully regenerated will show many survived cells in meristematic region [44].

PLBs made up of shoot apical meristem are able to regenerate into plantlets [45]. According to Volk and Caspersen [9], structural changes following cryopreservation allow the determination of cell sensitivity based on its type. Smaller cells such as meristem, upper cortex, and young leaf are less vulnerable to osmotic stress and plasmolysis during dehydration process. According to histological observation by N'Nan et al. [44], survival cell displayed isodiametric structure, dense cytoplasm with high nucleus-cytoplasm ratio, and spherical nucleus in a central position. Feng et al. [46] observed that the untreated cells showed dense staining and well-preserved cytoplasm in leaf primordial and apical dome. This is comparable with the present study, and the cross-section of stock culture PLB displayed intact cell with dense cytoplasm and small periplasmic space. Dense cytoplasm on the anterior of PLBs would continue to develop 
into a complete sheath leaf that would further enlarge and develop into true leaves [47].

In the present study, histological observation revealed that cell damage is mostly caused by cryoinjury during cooling and warming. Ineffective cryoprotection can be due to inhomogeneous tissue within the plant. Thus, several parts of the tissue can survive from cryopreservation through transformation into glassy state while other tissue parts do not survive as a result of ice formation and cell disintegration during rewarming [10]. In cryopreservation of orchid using PVS3 vitrification method, Mubbarakh et al. [45] reported the incidence of plasmolysis after cryopreservation. Cell membrane rupture with less dense cytoplasm, voluminous nucleus, increase in starch grains, and thickening of the cell wall was observed. The similar pattern of cell was observed in the present study. Cryopreserved cells displayed less stained, cytoplasm shrunk, and large periplasmic space (low nucleocytoplasm ratio) and highly stained nucleus (Figure 3(a)). Voluminous nucleus without a visible nucleolus suggested that nuclei experience osmotic stress [48]. Compact and deeply stained nucleus indicates that chromatin remains condensed and probably no transcription or protein synthesis for mitosis would be possible $[11,48]$. In contrast to this study, the mitotic activity still exists in cryopreserved PLB although the nuclei are deeply stained (Figure 3(b)).

Angiosperms own a mechanism of resistance against dehydration where it builds up polysaccharide compounds in cells [49]. Survival of cell after thaw cryopreservation can be manipulated by optimising sucrose concentration and preculture duration [50]. During dehydration and chilling process, sugar stabilizes and maintains plasma lemma integrity by replacing water molecules and forms hydrogen bonding with the polar head group of membrane phospholipid. Therefore, cells without starch grains did not survive after cryopreservation [45]. According to Ganino et al. [51], sucrose treatment could increase starch accumulation and protect cell integrity, while exposure to PVS2 leads the cell to experience plasmolysis. Preculture of shoot tips on low sucrose media showed starch accumulation in meristematic cortex and leaf primordial [52-54], while preculture in higher sucrose concentration resulted in concave plasmolysis [9]. In the present study, noncryopreserved PLB displayed intact cells with starch accumulation and thickening of cell wall (Figure 2(a)). The cell walls are surrounded with proteins and enzymes that actively work to reform the wall during cell growth and prevent ruptures in the plasma membrane [55]. Likewise, it also thickens and strengthens during induced stress [56].

According to Poobathy et al. [15], cryoinjury did not occur at the exterior part of PLBs of Dendrobium sonia-28 as SEM observation of both cryopreserved and noncryopreserved PLBs showed intact epidermal layers. In contrast with this study, scanning electron micrograph of cryopreserved PLB showed damaging effect of cryopreservation procedures (Figure 4). Dehydration process caused PLB shrunk and cracks in cryopreserved PLB. Similar observations were reported in oil palm's polyembryonic and Dendrobium Bobby Messina's PLB $[13,14]$. The damage in cell might result due to plasmolysis incidence which related based on histological analysis [57].

In this study, total soluble protein, ascorbate peroxidase, and catalase activities were measured as an indication of oxidative stress encountered by PLB of Brassidium Shooting Star during cryopreservation. Catalase and ascorbate peroxidases are part of antioxidant protection system enzymes which scavenge the reactive oxygen species in plants. These enzymes are largely confined to removal of hydrogen peroxide [58]. Increasing in protein expression was believed as one of the physiological responses against osmotic stress and may be induced by freezing tolerance mechanism $[59,60]$. It has been suggested that plants under stress may build up such amount of proteins that are used as a source of storage of nitrogen which could be activated after stress relief [61]. Study of the effects of cryopreservation on protein expression in potato found that preculture treatment did not increase the protein content compared to the control [10]. Steady decrease in protein expression was observed after preculture step [10].

In contrast with the present study, total soluble protein in precultured PLBs showed drastically increased from control PLBs (Figure 5). However, increasing in catalase and ascorbate activity did not significantly observe in preculture treatment (Figures 6 and 7). This may be due to the accumulation of soluble sugar during preculture treatment in highly concentrated media, which may further change the protein metabolism to induce cell tolerance [62].

Most of the plant suffered from osmotic stress during osmoprotection and dehydration process. Wen et al. [63] observed that dehydration and freezing extensively increase APX activity in maize's embryo culture. Significant increase in catalase and ascorbate peroxidase activities after the PVS2 dehydration and cryostorage treatment may indicate excess production of superoxide as a result of osmotic and dehydration during cryopreservation [64]. On the other hand, decrease in catalase and peroxidase activities could result in accumulation of intracellular hydrogen peroxide and this phenomenon was correlated with tissue browning [65]. In contrast with enzyme activity, PVS2 treatment did not enhance the total soluble protein in PLBs. This is due to the vitrified state which was able to stabilize proteins in cells [66]. In the study on wheat species, Baek and Skinner [67] evaluated the expression of antioxidant enzyme such as SOD and catalase that increased after cold acclimation. Increasing of antioxidants expression in the plant provides the better tolerance to oxidative stress [68]. Study on genotypic tolerance of Ribes confirmed that more tolerant genotype exhibited higher level of antioxidant throughout recovery whereas sensitive genotype showed no difference in oxidative stress markers [25].

Microscopy and biochemical studies proved that during dehydration and storage in liquid nitrogen generated the most oxidative stress. Nevertheless, viability of PLBs was not closely related to changes in cellular structure but antioxidant enzyme activity. Therefore, to enhance the growth percentage of cryopreserved PLBs, additional studies should be made on the supplementation of exogenous antioxidants during cryopreservation stages. 


\section{Conflict of Interests}

The authors declare that there is no conflict of interests regarding the publication of this paper.

\section{Authors' Contribution}

Safrina Rahmah made a major contribution to conducting experiments. Sreeramanan Subramaniam was involved in overall planning and supervision. Safiah Ahmad Mubbarakh and Khor Soo Ping were involved in experiments and planning.

\section{Acknowledgment}

The authors are grateful to USM Short Term 2012 for funding this project.

\section{References}

[1] H. Bouman and G. J. D. Klerk, "Cryopreservation of lily meristems," Acta Horticulturae, vol. 266, pp. 331-338, 1990.

[2] R. L. Dressler, Phylogeny and Classification of the Orchid Family, Harvard University Press, Cambridge, Mass, USA, 1993.

[3] G. H. Yue, L. T. Lam-Chan, and Y. Hong, "Development of simple sequence repeat (SSR) markers and their use in identification of Dendrobium varieties," Molecular Ecology Notes, vol. 6, no. 3, pp. 832-834, 2006.

[4] A. D. Hieber, R. G. Mudalige-Jayawickrama, and A. R. Kuehnle, "Color genes in the orchid Oncidium Gower Ramsey: identification, expression, and potential genetic instability in an interspecific cross," Planta, vol. 223, no. 3, pp. 521-531, 2006.

[5] A. Sakai and F. Engelmann, "Vitrification, encapsulationvitrification and droplet-vitrification: a review," CryoLetters, vol. 28, no. 3, pp. 151-172, 2007.

[6] A. Sakai, D. Hirai, and T. Niino, "Development of PVS-based vitrification and encapsulation-vitrification protocols," in Plant Cryopreservation: A practical Guide, B. M. Reed, Ed., pp. 33-57, Springer, Berlin, Germany, 2008.

[7] F. Engelmann, "Use of biotechnologies for the conservation of plant biodiversity," In Vitro Cellular \& Developmental BiologyPlant, vol. 47, pp. 5-16, 2011.

[8] B. Wen, C. Cai, R. Wang, S. Song, and J. Song, "Cytological and physiological changes in recalcitrant Chinese fan palm (Livistona chinensis) embryos during cryopreservation," Protoplasma, vol. 249, no. 2, pp. 323-335, 2012.

[9] G. M. Volk and A. M. Caspersen, "Plasmolysis and recovery of different cell types in cryoprotected shoot tips of Mentha $x$ piperita," Protoplasma, vol. 231, no. 3-4, pp. 215-226, 2007.

[10] A. Kaczmarczyk, T. Rutten, M. Melzer, and E. R. J. Keller, "Ultrastructural changes associated with cryopreservation of potato (Solanum tuberosum L.) shoot tips," CryoLetters, vol. 29, no. 2, pp. 145-156, 2008.

[11] P. Berjak, M. Walker, D. J. Mycock, J. Wesley-Smith, P. Watt, and N. W. Pammenter, "Cryopreservation of recalcitrant zygotic embryos," in Cryopreservation of Tropical Plant Germplasm, F. Engelmann and H. Takagi, Eds., pp. 140-155, IPGRI, Rome, Italy, 2000.
[12] B. Helliot, R. Swennen, Y. Poumay, E. Frison, P. Lepoivre, and B. Panis, "Ultrastructural changes associated with cryopreservation of banana (Musa spp.) highly proliferating meristems," Plant Cell Reports, vol. 21, no. 7, pp. 690-698, 2003.

[13] P. Suranthran, S. Gantait, U. R. Sinniah, S. Subramaniam, S. S. R. S. Alwee, and S. H. Roowi, "Effect of loading and vitrification solutions on survival of cryopreserved oil palm polyembryoids," Plant Growth Regulation, vol. 66, no. 2, pp. 101-109, 2012.

[14] J. J. J. Antony, S. A. Mubbarakh, M. Mahmood, and S. Subramaniam, "Effect of plasmolysis on protocorm-like bodies of Dendrobium Bobby Messina orchid following cryopreservation with encapsulation-dehydration method," Applied Biochemistry and Biotechnology, vol. 172, no. 3, pp. 1433-1444, 2014.

[15] R. Poobathy, U. R. Sinniah, X. Rathinam, and S. Subramaniam, "Histology and scanning electron microscopy observations of cryopreserved protocorm-like bodies of Dendrobium sonia-28," Turkish Journal of Biology, vol. 37, no. 2, pp. 191-198, 2013.

[16] E. E. Benson, Free Radical Damage in Stored Plant Germplasm, International Board for Plant Genetic Resources, Rome, Italy, 1990.

[17] C. H. Foyer and J. Harbinson, "Oxygen metabolism and the regulation of photosynthetic electron transport," in Causes of Photooxidative Stress and Amelioration of Defense System in Plants, C. H. Foyer and P. M. Mullineaux, Eds., pp. 1-42, CRC Press, Boca Raton, Fla, USA, 1994.

[18] K. Apel and H. Hirt, "Reactive oxygen species: metabolism, oxidative stress, and signal transduction," Annual Review of Plant Biology, vol. 55, pp. 373-399, 2004.

[19] S. S. Gill and N. Tuteja, "Reactive oxygen species and antioxidant machinery in abiotic stress tolerance in crop plants," Plant Physiology and Biochemistry, vol. 48, no. 12, pp. 909-930, 2010.

[20] L.-J. Quan, B. Zhang, W.-W. Shi, and H.-Y. Li, "Hydrogen peroxide in plants: a versatile molecule of the reactive oxygen species network," Journal of Integrative Plant Biology, vol. 50, no. 1, pp. 2-18, 2008.

[21] S. J. Jadhav, S. S. Nimbalkar, A. D. Kulkarni, and D. L. Madhavi, "Lipid oxidation in biological and food systems," in Food Antioxidants, L. D. Madhavi, S. S. Deshpande, and D. K. Salunkhe, Eds., pp. 5-63, Marcel Dekker, New York, NY, USA, 1996.

[22] E. E. Benson, P. T. Lynch, and J. Jones, "The use of the iron chelating agent desferrioxamine in rice cell cryopreservation: a novel approach for improving recovery," Plant Science, vol. 110, no. 2, pp. 249-258, 1995.

[23] R. A. Fleck, E. E. Benson, D. H. Bremner, and J. G. Day, "Studies of free radical-mediated cryoinjury in the unicellular green alga Euglena gracilis using a non-destructive hydroxyl radical assay: a novel approach for developing protistan cryopreservation strategies," Free Radical Research, vol. 32, no. 2, pp. 157-170, 2000.

[24] R. A. Fleck, E. E. Benson, D. H. Bremner, and J. G. Day, "A comparative study of antioxidant protection in cryopreserved unicellular algae: euglena gracilis and Haematococcus pluvialis," Cryo-Letters, vol. 24, no. 4, pp. 213-228, 2003.

[25] J. W. Johnston, K. Harding, and E. E. Benson, "Antioxidant status and genotypic tolerance of Ribes in vitro cultures to cryopreservation," Plant Science, vol. 172, no. 3, pp. 524-534, 2007.

[26] P. T. Lynch, A. Siddika, J. W. Johnston et al., "Effects of osmotic pretreatments on oxidative stress, antioxidant profiles and cryopreservation of olive somatic embryos," Plant Science, vol. 181, no. 1, pp. 47-56, 2011. 
[27] R. Mittler, "Oxidative stress, antioxidants and stress tolerance," Trends in Plant Science, vol. 7, no. 9, pp. 405-410, 2002.

[28] T. Vellosillo, J. Vicente, S. Kulasekaran, M. Hamberg, and C. Castresana, "Emerging complexity in reactive oxygen species production and signaling during the response of plants to pathogens," Plant Physiology, vol. 154, no. 2, pp. 444-448, 2010.

[29] E. López-Huertas, F. J. Corpas, L. M. Sandalio, and L. A. del Río, "Characterization of membrane polypeptides from pea leaf peroxisomes involved in superoxide radical generation," Biochemical Journal, vol. 337, no. 3, pp. 531-536, 1999.

[30] A. A. Ali and F. Alqurainy, "Activities of antioxidants in plants under environmental stress," in The Lutein-Prevention and Treatment for Diseases, N. Motohashi, Ed., pp. 187-256, Transworld Research Network, 2006.

[31] T. Karuppanapandian, J.-C. Moon, C. Kim, K. Manoharan, and W. Kim, "Reactive oxygen species in plants: their generation, signal transduction, and scavenging mechanisms," Australian Journal of Crop Science, vol. 5, no. 6, pp. 709-725, 2011.

[32] K. Asada, "The water-water cycle as alternative photon and electron sinks," Philosophical Transactions of the Royal Society B: Biological Sciences, vol. 355, pp. 1419-1431, 2000.

[33] S. Sarowar, E. N. Kim, Y. J. Kim et al., "Overexpression of a pepper ascorbate peroxidase-like 1 gene in tobacco plants enhances tolerance to oxidative stress and pathogens," Plant Science, vol. 169, no. 1, pp. 55-63, 2005.

[34] M. M. Bradford, "A rapid and sensitive method for the quantitation of microgram quantities of protein utilizing the principle of protein dye binding," Analytical Biochemistry, vol. 72, no. 1-2, pp. $248-254,1976$.

[35] Y. Nakano and K. Asada, "Hydrogen peroxide is scavenged by ascorbate-specific peroxidase in spinach chloroplasts," Plant and Cell Physiology, vol. 22, no. 5, pp. 867-880, 1981.

[36] I. Cakmak and H. Marschner, "Magnesium deficiency and high light intensity enhance activities of superoxide dismutase, ascorbate peroxidase, and glutathione reductase in bean leaves," Plant Physiology, vol. 98, no. 4, pp. 1222-1227, 1992.

[37] F. Monnet, F. Bordas, V. Deluchat, and M. Baudu, "Toxicity of copper excess on the lichen Dermatocarpon luridum: antioxidant enzyme activities," Chemosphere, vol. 65, no. 10, pp. 18061813, 2006.

[38] S. Elavarthi and B. Martin, "Spectrophotometric assays for antioxidant enzymes in plants," in Plant Stress Tolerance, R. Sunkar, Ed., Methods in Molecular Biology, pp. 273-280, Springer, Berlin, Germany, 2010.

[39] S. Samantary, "Biochemical responses of Cr-tolerant and Crsensitive mung bean cultivars grown on varying levels of chromium," Chemosphere, vol. 47, no. 10, pp. 1065-1072, 2002.

[40] T. Tijssen, "Enzymes for immunoassays," in Practice and Theory of Enzyme Immunoassays, R. H. Burdon and P. H. Knippenberg, Eds., pp. 173-220, Elsevier, Amsterdam, The Netherlands, 1985.

[41] C. G. Flocco and A. M. Giulietti, "Methods in biotechnology," in Phytoremediation: Methods and Reviews, N. Wiley, Ed., vol. 23, pp. 161-173, Humana Press, Totowa, NJ, USA, 2007.

[42] G. M. Volk and C. Walters, "Plant vitrification solution 2 lowers water content and alters freezing behavior in shoot tips during cryoprotection," Cryobiology, vol. 52, no. 1, pp. 48-61, 2006.

[43] K. Muldrew, J. P. Acker, J. A. W. Elliot, and L. E. McGann, “The water to ice transition: implications for living cells," in Life in the Frozen State, B. Fuller, N. Lane, and E. E. Benson, Eds., pp. 67-108, CRC Press, Boca Raton, Fla, USA, 2004.
[44] O. N’Nan, V. Hocher, J.-L. Verdeil et al., "Cryopreservation by encapsulation-dehydration of plumules of coconut (Cocos nucifera L.)," Cryo-Letters, vol. 29, no. 4, pp. 339-350, 2008.

[45] S. A. Mubbarakh, S. Rahmah, Z. A. Rahman, N. N. M. Sah, and S. Subramaniam, "Cryopreservation of brassidium shooting star orchid using the PVS3 method supported with preliminary histological analysis," Applied Biochemistry and Biotechnology, vol. 172, no. 2, pp. 1131-1145, 2014.

[46] C.-H. Feng, Z.-H. Cui, B.-Q. Li et al., "Duration of sucrose preculture is critical for shoot regrowth of in vitro-grown apple shoot-tips cryopreserved by encapsulation-dehydration," Plant Cell, Tissue and Organ Culture, vol. 112, no. 3, pp. 369-378, 2013.

[47] C.-Y. Ng and N. M. Saleh, "In vitro propagation of Paphiopedilum orchid through formation of protocorm-like bodies," Plant Cell, Tissue and Organ Culture, vol. 105, no. 2, pp. 193-202, 2011.

[48] N. Michaux-Ferriere, "Etude ultrastructurale de la digestion des lipides chez l' Isoetes setacea Lam. lors de la rehydratation," Zeitschrift für Pflanzenphysiologie, vol. 111, no. 2, pp. 183-188, 1980.

[49] A. C. Leopold and N. Ferriere, in Stress Responses in Plants: Adaptation and Acclimation Mechanisms, R. G. Alscher and J. R. Cumming, Eds., pp. 7-56, Wiley-Liss, New York, NY, USA, 1980.

[50] Q. C. Wang, W. J. Cuellar, M. L. Rajamaki, Y. Hiraka, and J. P. Valkonen, "Combined thermotherapy and cryotherapy for efficient virus eradication: relation of virus distribution, subcellular changes, cell survival and viral RNA degradation in shoot tips," Molecular Plant Pathology, vol. 9, pp. 37-50, 2008.

[51] T. Ganino, A. Silvanini, D. Beghé, C. Benelli, M. Lambardi, and A. Fabbri, "Anatomy and osmotic potential of the Vitis rootstock shoot tips recalcitrant to cryopreservation," Biologia Plantarum, vol. 56, no. 1, pp. 78-82, 2012.

[52] M. T. Gonzalez-Arnao, F. Engelmann, C. Huet, and C. Urra, "Cryopreservation of encapsulated apices of sugarcane: effect of freezing procedure and histology," CryoLetters, vol. 14, pp. 303308, 1993.

[53] A. Grapin, A. Gallard, and M. Chevalier, "Cryopreservation of Pelargonium species: a comparative study of encapsulationdehydration and droplet-vitrification protocols," Acta Horticulturae, vol. 918, pp. 131-137, 2011.

[54] G. Barraco, I. Sylvestre, and F. Engelmann, "Comparing encapsulation-dehydration and droplet-vitrification for cryopreservation of sugarcane (Saccharum spp.) shoot tips," Scientia Horticulturae, vol. 130, no. 1, pp. 320-324, 2011.

[55] R. F. Evert and K. Esau, Esau's Plant Anatomy: Meristems, Cells, and Tissues of the Plant Body: Their Structure, Function, and Development, John Wiley \& Sons, Hoboken, NJ, USA, 3rd edition, 2006.

[56] B. C. Freeman and G. A. Beattie, The Plant Health Instructor, 2008.

[57] X. L. You, J. S. Yi, and Y. E. Choi, "Cellular change and callose accumulation in zygotic embryos of Eleutherococcus senticosus caused by plasmolyzing pretreatment result in high frequency of single-cell-derived somatic embryogenesis," Protoplasma, vol. 227, no. 2-4, pp. 105-112, 2006.

[58] S. Klapheck, I. Zimmer, and H. Cosse, "Scavenging of hydrogen peroxide in the endosperm of ricinus communis by ascorbate peroxidase," Plant and Cell Physiology, vol. 31, no. 7, pp. 10051013, 1990. 
[59] Y. Jitsuyama, T. Suzuki, T. Harada, and S. Fujikawa, "Sucrose incubation increases freezing tolerance of Asparagus (Asparagus officinalis L.) embryogenic cell suspensions," CryoLetters, vol. 23, no. 2, pp. 103-112, 2002.

[60] Q. Wang, M. Mawassi, N. Sahar et al., "Cryopreservation of grapevine (Vitis spp.) embryogenic cell suspensions by encapsulation-vitrification," Plant Cell, Tissue and Organ Culture, vol. 77, no. 3, pp. 267-275, 2004.

[61] N. K. Singh, C. A. Bracker, P. M. Hasegawa et al., "Characterization of osmotin: a thaumatin-like protein associated with osmotic adaptation in plant cells," Plant Physiology, vol. 85, no. 2, pp. 529-536, 1987.

[62] G.-Y. Zhu, J. M. C. Geuns, S. Dussert, R. Swennen, and B. Panis, "Change in sugar, sterol and fatty acid composition in banana meristems caused by sucrose-induced acclimation and its effects on cryopreservation," Physiologia Plantarum, vol. 128, no. 1, pp. 80-94, 2006.

[63] B. Wen, R. Wang, H. Cheng, and S. Song, "Cytological and physiological changes in orthodox maize embryos during cryopreservation," Protoplasma, vol. 239, no. 1-4, pp. 57-67, 2010.

[64] T. Roach, M. Ivanova, R. P. Beckett et al., "An oxidative burst of superoxide in embryonic axes of recalcitrant sweet chestnut seeds as induced by excision and desiccation," Physiologia Plantarum, vol. 133, no. 2, pp. 131-139, 2008.

[65] H. Laukkanen, H. Häggman, S. Kontunen-Soppela, and A. Hohtola, "Tissue browning of in vitro cultures of Scots pine: role of peroxidase and polyphenol oxidase," Physiologia Plantarum, vol. 106, no. 3, pp. 337-343, 1999.

[66] W. Q. Sun, P. Davidson, and H. S. O. Chan, "Protein stability in the amorphous carbohydrate matrix: relevance to anhydrobiosis," Biochimica et Biophysica Acta-General Subjects, vol. 1425, no. 1, pp. 245-254, 1998.

[67] K.-H. Baek and D. Z. Skinner, "Alteration of antioxidant enzyme gene expression during cold acclimation of near-isogenic wheat lines," Plant Science, vol. 165, no. 6, pp. 1221-1227, 2003.

[68] A. Kaczmarczyk, B. Funnekotter, A. Menon et al., "Current issues in plant cryopreservation," in Current Frontiers in Cryobiology, I. I. Katkov, Ed., pp. 417-438, InTech, 2012. 

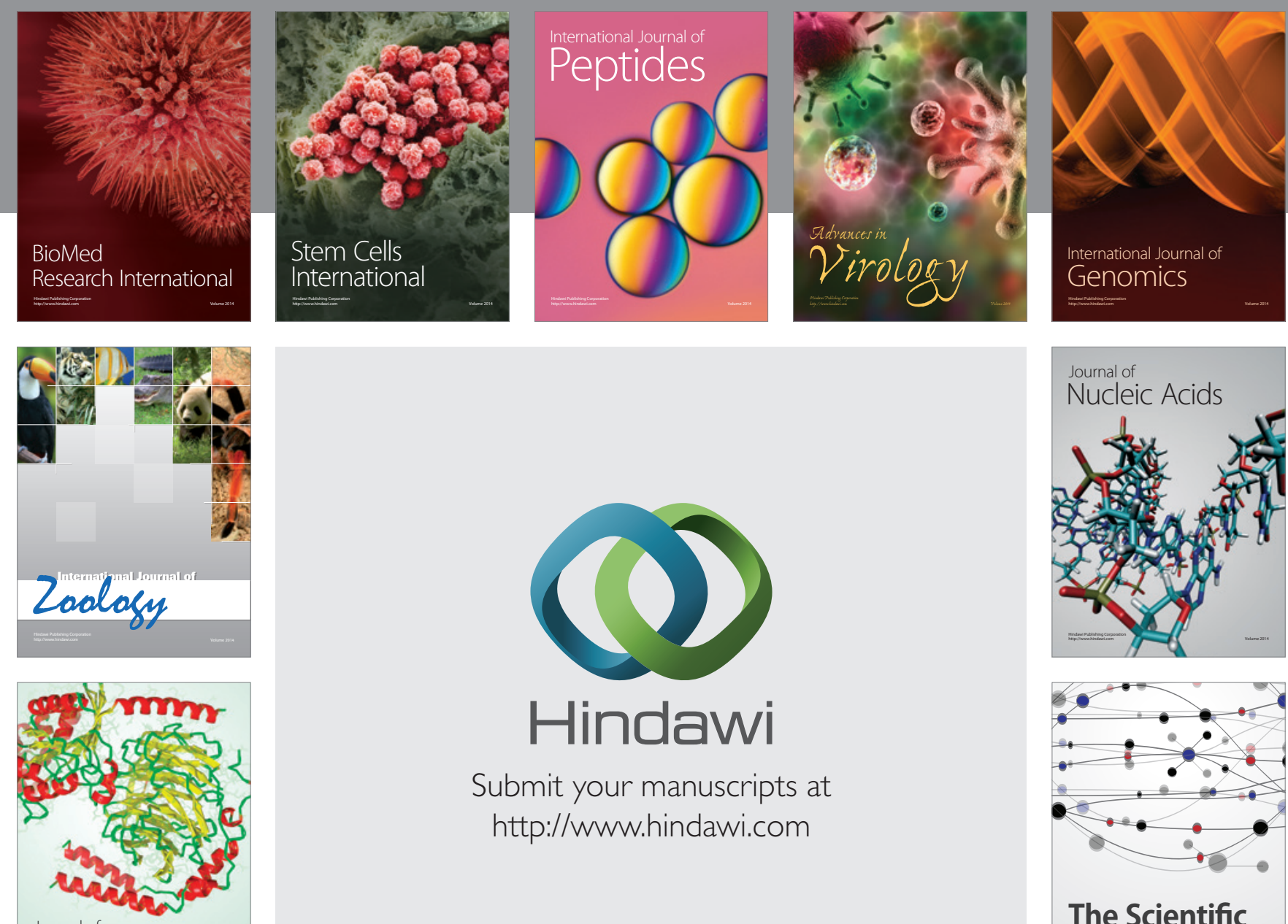

Submit your manuscripts at

http://www.hindawi.com

Journal of
Signal Transduction
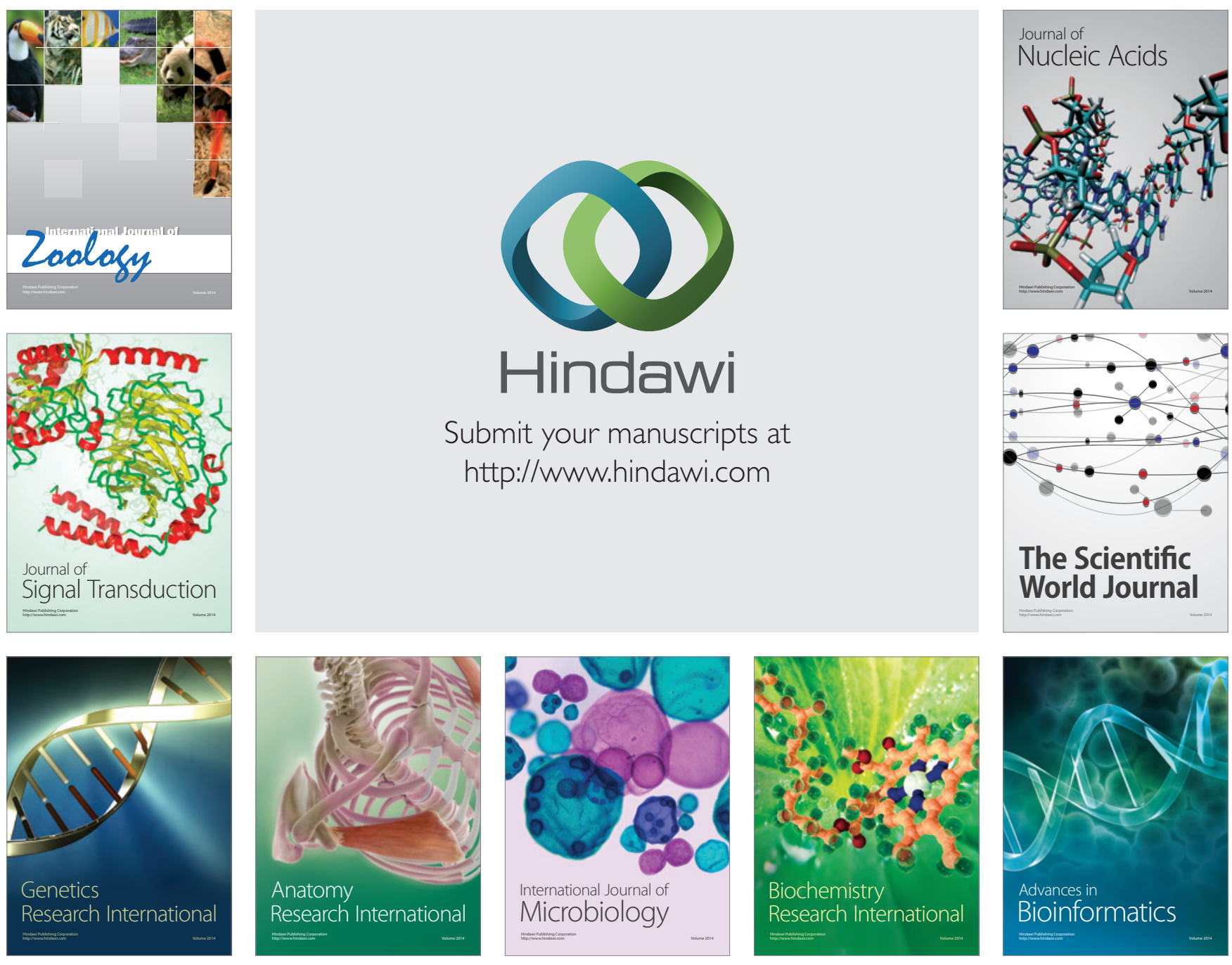

The Scientific World Journal
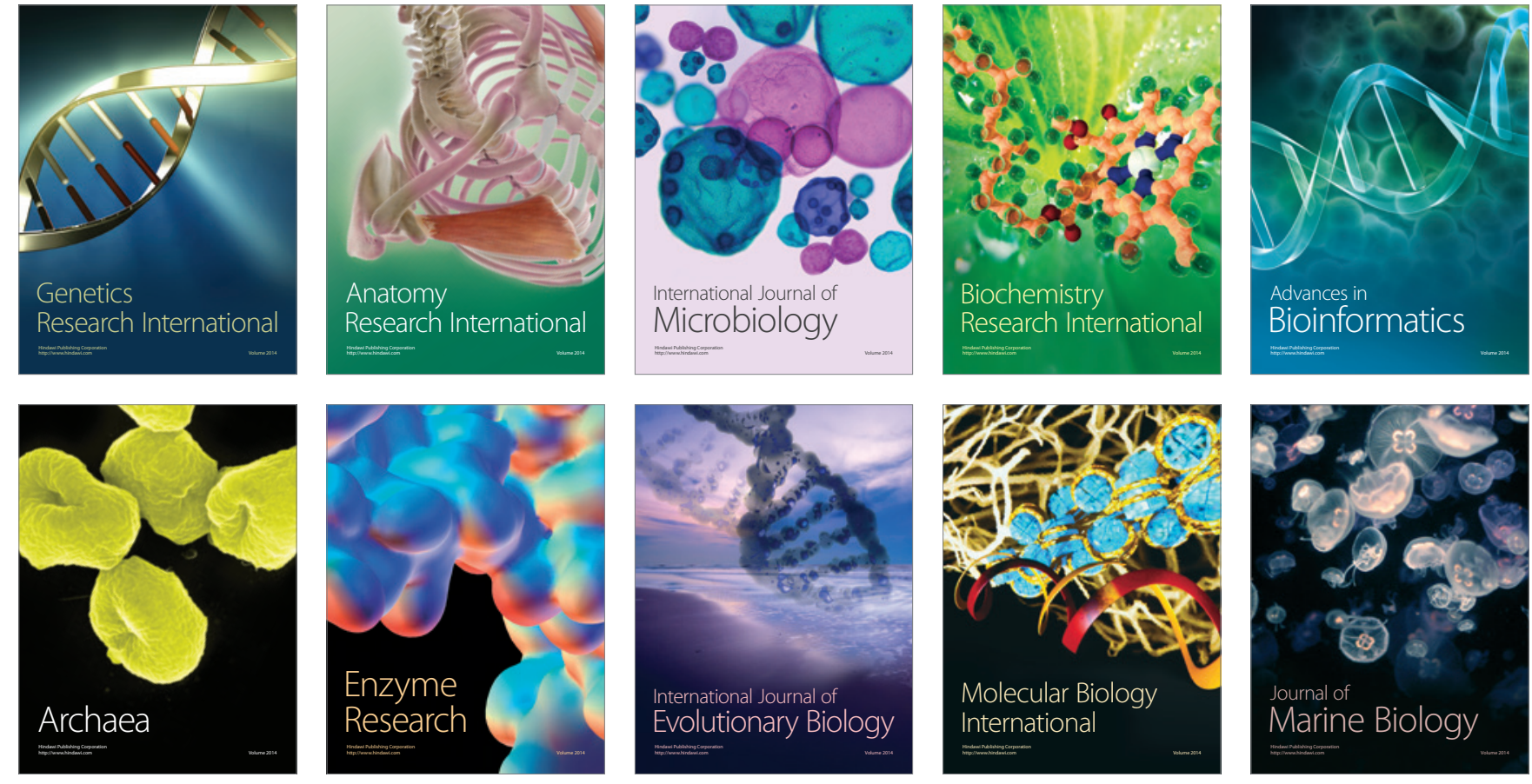